\title{
15 Intersections of Law, Human Rights and Water Management in Zimbabwe: Implications for Rural Livelihoods
}

\author{
Bill Derman, ${ }^{1}$ Anne Hellum, ${ }^{2}$ Emmanuel Manzungu, ${ }^{3}$ \\ Pinimidzai Sithole ${ }^{4}$ and Rose Machiridza ${ }^{5}$ \\ ${ }^{1}$ Department of Anthropology, Michigan State University, USA and Department of \\ International Environment and Development Studies (NORAGRIC), Norwegian \\ University of Life Sciences, Norway; e-mail: derman@msu.edu or \\ bill.derman@umb.no; ${ }^{2}$ Faculty of Law, University of Oslo, Oslo, Norway; \\ e-mail: anne.hellum@jus.uio.no; ${ }^{3}$ Department of Soil Science and Agricultural \\ Engineering, University of Zimbabwe, Harare, Zimbabwe; \\ e-mail: manzungu@mweb.co.zw; ${ }^{4}$ Centre for Applied Social Sciences, University of \\ Zimbabwe, Harare, Zimbabwe; e-mail: spinimidzai@yahoo.com; ${ }^{5}$ Department of Soil \\ Science and Agricultural Engineering, University of Zimbabwe, Harare, Zimbabwe; \\ e-mail: roma877@yahoo.co.uk
}

\begin{abstract}
As poverty has increased in Zimbabwe and elsewhere in Africa, the importance of water for smallholder agriculture has intensified. This chapter draws attention to the human right to water adopted in General Comment 15 by the Committee on Economic, Social and Cultural Rights, supplanting the Dublin Principles, which have too often been understood in the African context to mean water with the 'right' price. The chapter relates this human rights framework for law and policy, embedded in international and regional African instruments, to the history of national water legislation in Zimbabwe and its recent water reform. We ask how the historically evolving component of 'Primary Water Rights' tallies, or not, with international human rights approaches. It also traces the implications for rural livelihoods of the recently introduced obligation to pay fees for any water use that exceeds these 'primary water uses'. Further, the international human rights approach to water and the national notion of 'primary water uses' are compared with the multiple ways in which men and women share and manage land and water, including local norms and practices within a broader right to livelihood. Field research in Zimbabwe suggests the existence of a right to water and livelihood in local water management that can respond better to poverty and gender inequities. We suggest that a right to livelihood could be used for an active research programme to examine integration of local norms and practices within water management laws and policies and small-scale irrigation as an alternative to the overemphasis upon large-scale commercial agriculture.
\end{abstract}

Keywords: human rights, rights to water and livelihood, small-scale agriculture, local norms, gender discrimination, Zimbabwe. 


\section{Introduction}

Water forms part of a broad 'right to life' that underlies rural livelihoods in Zimbabwe. It is expressed in the Romwe Catchment in southern Zimbabwe as 'water is life' (hupenyu) (Nemarundwe, 2003), in Shamva district as 'drinking water should be for everyone' (Matondi, 2001) and in Mhondoro Communal area as 'one can't deny drinking water to anyone' (Derman and Hellum, 2003). This right endures despite efforts by both colonial and independent governments to redefine rural citizens' relationship to water. The newly enunciated international human right to water accords well with the practices and norms within most, if not all, of Zimbabwe's communal and resettlement areas, but does not fit with either the colonial past or the current focus of water reform efforts. The idea that to deny water is to deny life indicates a profounder truth that there can be no human life without water. To deny people water denies them life.

The United Nations has included 'a right to water' in the International Covenant on Economic, Social and Cultural Rights (ICESCR), 1966 in its development policy. ${ }^{1}$ In its global report on water, Water for People, Water for Life, the United Nations Educational and Scientific Organization (2003) emphasizes the right to water explicitly. This right is implicitly recognized in the Convention on the Rights of the Child (CRC), 1989, in the Convention on the Elimination of All Forms of Discrimination Against Women (CEDAW), 1979 and in the General Comment on the Right to Health, 2000. The previous global consensus around the Dublin Principles ${ }^{2}$, with its emphasis upon water as an economic and social good, seems to be receding in the face of a growing movement toward recognizing a human right to water as an axiom for development and poverty-elimination policies. The Millennium Development Goal aimed at halving the number of people without clean drinking water emphasizes the critical importance of clean water. The World Bank, which had been in the forefront of arguing that water was not a human right but an economic good that required proper financing (World Bank, 1993, 2002, 2003a), has shifted toward examining human rights and equity (Salman and McInerney-
Lankford, 2004). It would seem that the many elements of the global system are catching up with villagers.

National water legislation and recent reform involve how a nation's waters are managed and understood. In this respect it is important to understand the colonial roots of water legislation in Zimbabwe, which protected and developed water resources in the interest of the colonial settlers at the expense of Africans, whose access to water was minimal and therefore largely falling under 'primary water uses' (see below). Entrenched inequities were factually perpetuated under Zimbabwe's water reforms in the 1990s that were enacted principally with the four Dublin Principles, rather than the human rights' framework, in mind. The principles fit better with the long-standing state biases toward large-scale commercial agriculture, and are at variance with what happens in the communal areas where the majority of the people live. In these areas, residents cultivate small plots, drawing upon local norms and practices and often resisting unsympathetic state policies. A common feature of local norms and practices, as observed in a wide range of contemporary studies of natural resources management in Zimbabwe's rural areas and decentralization, is the emphasis on resources that are vital for livelihood, such as food and water. $^{3}$

In this chapter we identify local principles underlying access to water and land, and we have been surprised at the strength of fundamental norms despite a literature that emphasizes contestation and overlapping and conflicting spheres of authority. In turn, this has led us to examine if and how these normative local frameworks are consonant with some principles of the right to livelihood and right to water now embodied in a range of international human rights instruments, as well as within the current national legislation. This chapter connects researchers' observations on the principle of a 'right to water' in rural Zimbabwe with how that right could be considered within the broader context of a 'right to livelihood'. We suggest that the conceptual division made between land and water does not fit with local conceptions of livelihoods or the growing evidence of the importance of the land-water interface, which includes 'natural' wetlands and 
irrigation systems. We have chosen to probe these issues in Zimbabwe due to a long history of colonial state support for irrigation for white farmers, the difficulties in establishing smallholder irrigation and the contemporary processes of water reform in light of studies investigating water management. ${ }^{4}$

This chapter does not include in any depth the medium- and long-term implications of the current fast-track land reform programme (FTLP) underway for the 'right to water' and the 'right to livelihood' (Derman and Hellum, 2003; Hammar et al., 2003; Manzungu, 2003; Hellum and Derman, 2004, 2005). It is too early to speculate on what directions Zimbabwe will take after President Mugabe leaves office. However, one can observe that there has been a dramatic increase in the numbers of Zimbabwe's poor, a direct consequence of the FTLP. Zimbabwe has one of the highest rates of inflation in the world, combined with a shrinking economy. In the past few years, it has fallen from a medium human-development nation to a low one (Human Development Report, 2003), and was ranked 147th out of 177 in the global human development index. High rates of education (now dropping rapidly) keep Zimbabwe from the bottom. Due to HIV/AIDS, population growth is projected to be at $0.2 \%$ of the annual growth rate. Life expectancy at birth has fallen from 56.0 to 33.1 , perhaps the most powerful indicator of failed policies.

In this context, there needs to be a much greater coordination between water policies and poverty alleviation strategies. The question that can be asked is whether the global water agenda, with its emphasis on commercialization, effectively engages with local realities in a collapsing country like Zimbabwe, whose political leadership first brought in neo-liberalism for a time but then rejected it (Manzungu, 2002). ${ }^{5}$ In the context of Zimbabwe, attention to the local gains is of increased importance, since villagers are far more reliant upon their own resources than before.

This chapter proceeds as follows: in section 1 we detail the emergence of the right to livelihood and the right to water in the United Nations system, the African Union and other international and national forums. We do this to examine how a human right can be constructed on the basis of other human rights. If and how the human right to water becomes accepted and implemented remains to be decided, based upon many factors known and unknown. Section 2 considers Zimbabwe's water history, water reform and water management. In section 3 we examine the contemporary water reform programme, which was intended to address the inequalities produced by settler rule and realities of contemporary integrated water management. How local norms and practices respect rights to livelihood and water forms the substance of section 4 . While we note how little the new laws have affected these, we propose greater attention to those elements of local practice that are best conserved. In the conclusions, section 5 , we examine how human rights - with its obligations to protect, respect and fulfil - set new responsibilities for states to accomplish. This is a significant challenge in contemporary Zimbabwe, with its divergence from internationally accepted human rights standards. See Fig. 15.1 for a map of Zimbabwe.

\section{Water as a Part of the Human Right to Livelihood}

When Zimbabwe passed its new water acts the human right to water had not been explicitly recognized, although it had been included in some international conventions. ${ }^{6}$ In more general terms, the human right to water derives from the right to life, the right to livelihood and the right to health. It has evolved through piecemeal international, regional and national law-making. It is recognized in Article 24 of the Convention on the Rights of the Child, explicitly stating that the child has a right to clean drinking water. Article $14.2 \mathrm{~h}$ of the Convention on the Elimination of all forms of Discrimination Against Women states that rural women have a right to 'enjoy adequate living conditions, particularly in relation to housing, sanitation, electricity and water supply, transport and communications' on an equal basis with men. Article 15 of the Protocol to the African Charter on Human and Peoples' Rights on the Rights of Women in Africa on the right to food ${ }^{7}$ obliges states partly to "provide women with access to clean drinking water, sources of domestic fuel, land and the means of producing nutritious food'. The human right to water is also recognized in the United Nations Convention on 


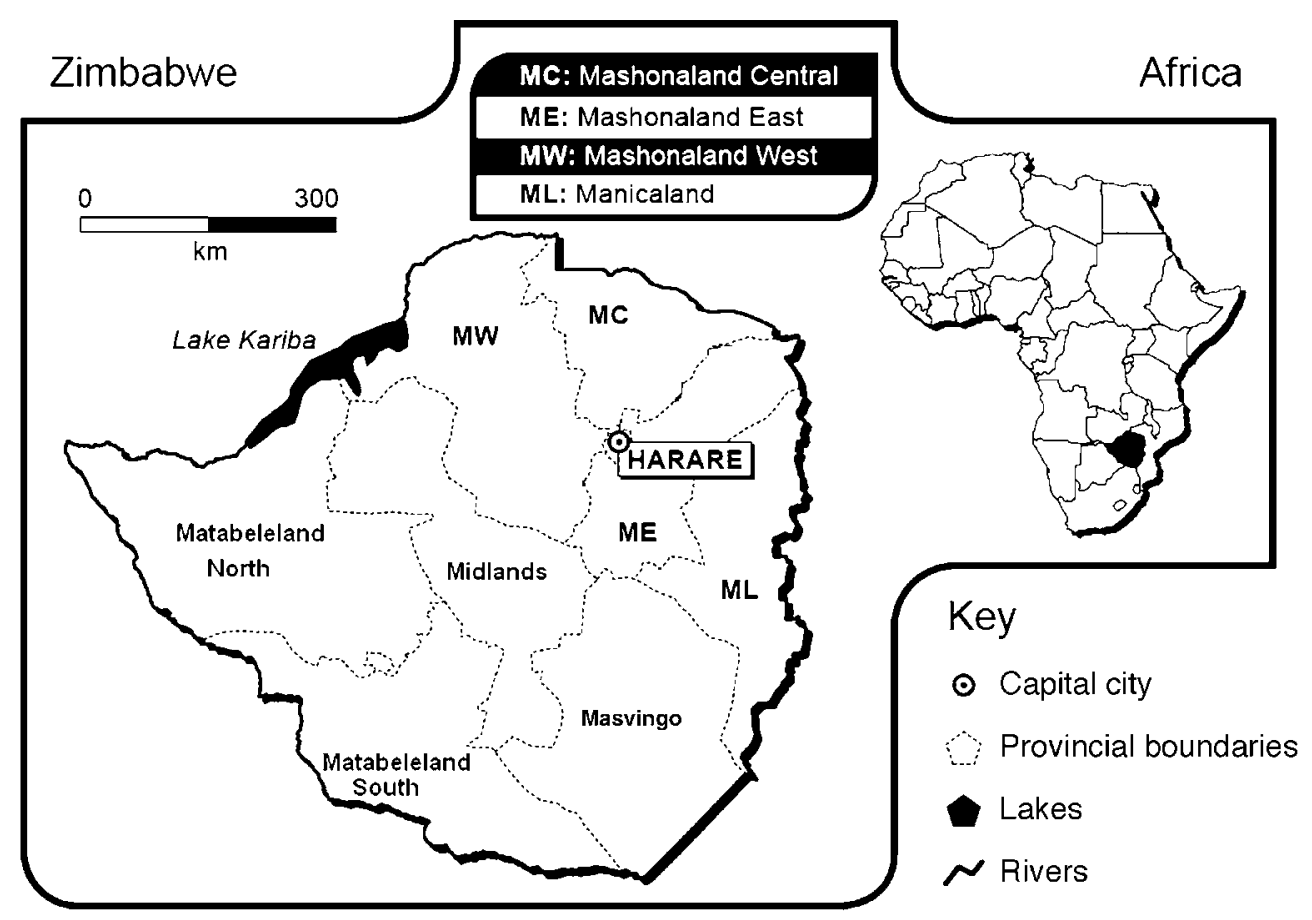

Fig. 15.1. Map of Zimbabwe.

the Law of Non-Navigational Uses of Watercourses. ${ }^{8}$

The Southern Africa Development Community (SADC) Protocol on Shared Water Course Systems of 1995 emphasizes equitable utilization of shared watercourses applying existing international law, existing practices and community interest taking into account, among other things, the environmental, social and economic needs and the impact of intended uses of the watercourse (Article 2).

\section{Safe, adequate and available water}

A major shift in underlining the significance of a right to water was the General Comment No. 15 of July 2002 by the UN Committee on Economic, Social and Cultural Rights, whereby the Committee concluded that there is a human right to water embedded in Article 11 in the Convention on Economic, Social and Cultural Rights (CESCR), defining the right to livelihood as 'including adequate food, clothing and housing'. The term 'including', as understood by the
Committee, indicates that the catalogue of rights encompassing the right to livelihood is not exhaustive but must be adapted to changing social and economic concerns such as the global water crisis (Eide, 2001). Concluding that water is a human right, the Committee (2002) emphasizes the interdependence between human rights in general and between access to water and the right to health in Article 12,1, the right to food in Article 11 and the right to life and human dignity enshrined in the International Bill of Human Rights (1948).

Recognizing that water is required for a range of different purposes that are essential for human life, the Committee on Economic, Social and Cultural Rights (2002) signalled three elements: (i) water must be adequate for human life; (ii) it must be safe and available; and (iii) it must be available on a non-discriminatory basis. Adequate water, according to the CESCR, is a far broader concept than just clean drinking water, since it encompasses water for personal and domestic uses and the necessary water resources to prevent starvation and disease. The scope and extent of the human right to water are 
defined through its link to the right to life, the right to health and the right to food. In the view of the CESCR, especially important is that sustainable access to water resources for agriculture is necessary to realize the right to adequate food (General Recommendation No. 12, 1999). Disadvantaged and marginalized farmers (women and men) should have equitable access to water and water management systems, including sustainable rain-harvesting and irrigation technology.

\section{State obligation to respect, protect and fulfil}

The obligation to respect, protect and fulfil rights cuts across urban and rural water supplies and services. The obligation to respect includes a duty to refrain from interfering arbitrarily with customary or traditional arrangements for water allocation, unlawfully polluting water or destroying water services and infrastructure during armed conflicts (General Recommendations 15, 23 and 24). Taking note of the duty in Article 1, paragraph 2 of the Covenant (1966), which provides that people cannot 'be deprived of their means of subsistence', states parties should ensure that there is adequate access to water for subsistence farming and for securing the livelihoods of indigenous peoples. This aspect of the human right to water is also expressed in the Statement of Understanding accompanying the United Nations Convention on the Law of Non-Navigational Uses of Watercourses (A/15/869 of 11 April 1997), which affirms that, in determining vital human needs in the event of conflicts over the use of watercourses, 'special attention is to be paid to providing sufficient water to sustain human life, including both drinking water and water required for production of food in order to prevent starvation'.

The obligation to protect as part of all human rights treaties and conventions requires state parties to prevent individuals, groups, corporations or other agents acting under their authority from interfering with the right to water. States parties are under an obligation to prevent private water service operators from compromising the right to equal, safe and affordable water in terms of regulatory systems, including independent monitoring, public participation and penalties for non-compliance (General Recommendations 15, 23 and 24).

As regards the duty to fulfil, states parties must, to ensure that water is affordable, adopt measures including: (i) use of a range of appropriate low-cost techniques and technologies; (ii) appropriate pricing policies such as free or lowcost water; and (iii) income supplements. Any payment for water services has to be based on the principle of equity, ensuring that these services, whether privately or publicly provided, are affordable for all, including socially disadvantaged groups. Equity demands that poorer households should not be disproportionately burdened with water expenses compared with richer households (General Recommendations 15, 26 and 27). This has implications for the implementation of the 'user pays' principle, which has become ubiquitous in both urban and rural settings.

Taking the human right to water beyond the nation state, the Committee on Social and Economic Human Rights in General Recommendation 15 also recommends that United Nations agencies and other international organizations concerned with water including all United Nations' organizations (World Health Organization, etc.) - should cooperate effectively with state parties in relation to the implementation of the right to water.

The Committee also recommends that the international financial institutions, notably the International Monetary Fund (IMF), the World Bank, the African Development Bank, etc. should take into account the rights to water in their lending policies, credit agreements, structural adjustment programmes and other development projects. The emerging literature on the human right to water by the World Bank and the World Health Organization (WHO) suggests a paradigmatic change (WHO, 2003; Salman and McInerney-Lankford, 2004).

\section{Non-discrimination}

State parties are also obliged to ensure that the right to water is enjoyed without discrimination on the grounds of sex, class, colour, religion or political opinion. State parties are to ensure that new laws, policies and programmes do not deny this right either de jure or de facto to selec- 
tive portions of the population. Inappropriate resource allocation can lead to indirect discrimination. Investment should, according to Comment 15, not disproportionately favour expensive water supply services and facilities that are available only to a small percentage of the population.

The CEDAW and Protocol to the African Charter on Human and Peoples' Rights on the Rights of Women ${ }^{9}$ in Africa substantiate the principle of non-discrimination in relation to water, land and food security. Simply having gender-neutral laws and policies in a situation where resources (time, money, land, water, for example) are unevenly distributed between men and women is insufficient. To ensure substantive equality CEDAW and the Protocol oblige state parties to take measures to eliminate both direct and indirect discrimination. ${ }^{10}$ Indirect discrimination points to the unintended effects of seemingly gender-neutral laws and policies. It is defined as 'any distinction, exclusion or restriction made on the basis of sex which has the effect that they impair or nullify, on a basis of equality between men and women, human rights in the political, economic, social, cultural, civil or any other field (CEDAW Article 1)'.

The concept of indirect discrimination encompasses development policies and programmes that, on face value, are gender-neutral but in practice are biased against large groups of female users in comparison with male water users (Hellum, 2007). Policies, programmes and plans for improvements and investments in water that are based on a division between domestic and productive water use will often have a discriminatory effect both in terms of class and gender. Women farmers' hand irrigation of small vegetable gardens has too often, for example, been seen as unproductive by conventional economic standards. Seemingly gender-neutral investment policies targeted towards productive water uses have, as a result, often disproportionately favoured larger or more expensive water supply services controlled by men. States parties to the CEDAW and the African Charter are obliged to take measures to eliminate this form of discrimination. In accordance with Article 26 of the Protocol to the African Charter on the Rights of Women in Africa, state parties are obliged to undertake to 'adopt all necessary measures and in particular provide budgetary and all other resources for the full and effective implementation of the rights'.

In the next section we trace how the human right to water, as defined internationally today, relates to the historical developments in water legislation in Zimbabwe and to the recent reform, in particular with regard to small-scale productive uses in rural areas.

\section{Water Legislation and Smallholder Irrigation in Zimbabwe}

Developments in water legislation and smallholder irrigation in Zimbabwe are closely linked with the country's socio-political history. In its simplified form this can be summarized in three phases. Between 1890 and 1980, the colonial state machinery favoured white settler political, social and economic interests at the expense of the black majority population. The attainment of independence in 1980 saw the post-colonial state seeking to redress the historical race, class and gender imbalances. The social expansion of health, education, agricultural extension and resettlement between 1980 and 1990 proved to be unsustainable as it was not supported by a strong economic base. This led to the IMF/World Bank-inspired Economic Structural Adjustment Programme (ESAP) of the 1990s. ESAP promoted economic deregulation to the extent that the anticipated economic and social gains were not achieved. From 1997 the economic malaise gave birth to complex political, economic and legal crises, which have resulted in the state being unable to deliver on political and economic rights. We provide below a synopsis of the major developments with regard to water.

\section{The early years: $1890-1927$}

In the early years, the colonial state's preoccupation with mining was reflected in the water sector. The interest changed to agriculture when it was apparent two decades later that mining was not going to be a profitable venture, as was the case in South Africa. In this endeavour there was scant regard paid to the rights of the black population. For example, in the allocation of 
water rights a frontier mentality was displayed with such claims as: '.. being a new country, Southern Rhodesia is unhampered by the pernicious common law relating to riparian ownership' (Manzungu and Senzanje, 1996). In this way the water rights of the black population that predated the settler claims were disregarded. But this is not to suggest that there was harmony within the settler community. In fact, conflicts over water within the settler community did not take long to develop. The frequent and often costly litigations between rival claimants to the use of water culminated in the Union Irrigation Act of 1912. This made provisions for the control, apportionment and use of water. The Act was based on the common law as evolved and expounded by the courts (Mcllwain, 1936). In 1913, the Water Ordinance was passed as a way of comprehensively dealing with problems of rights to water (Mcllwain, 1936).

The South African connection had a strong influence on some aspects of water management. For example the settlers, encouraged by the British South Africa Company (BSAC), used the Roman Dutch Law that had been brought from Holland and then in use in South Africa - by then the English riparian rights had already been adopted. This was regarded as unsuited to the water resources and production of the region (Mcllwain, 1936). There was, however, continued use of the riparian rights doctrine in interpreting access rights and differentiated water-use types. The 1920 Water Ordinance explained that: 'If a farmer has land well suited for irrigation and there is a stream that can be economically utilized, he can acquire the right to use the whole of the water for irrigation even though it may leave others without water except for primary purposes.'

While there were disagreements between the settlers over which was the better legal model to guide water allocation, the situation was worse for the black population. Land appropriation disadvantaged communal area residents since it left them downstream of white settlers with less ability to access water. In sum, the legal system was set against them, and compounded by a shortage of the necessary finance.

The concept of primary water use was provided for from the early years. Historically, primary water was a concept adopted from the earliest South African water laws. The first regu- lation of water in Zimbabwe was by the Order in Council, 1898, Section 81 pertaining to the British South Africa Company. It required the company to ensure that the natives or tribes had a fair and equitable portion of springs or permanent water. Primary water use was water for human and farm livestock use and was set at 50 gallons $(\sim 228$ 1)/person/day. This was quite generous because it could be used in and around the homestead, including gardening. Water for 'secondary purposes' was for irrigation and watering of stock other than farm stock. 'Tertiary purposes' included the needs of the mines and railways. While in theory there was nothing that stopped the black indigenous population benefiting from primary rights, a combination of lack of information and the dry terrain they were forced to inhabit did not help matters.

\section{Agriculture-based water law: 1927-1980}

With increasing water use by white farmers, new water laws were required to establish the 'rules of the game'. In 1927, for the positive requirement of fair and equitable availability of primary water for Tribal Trust Lands (TTL, what are now the Communal Areas), water use was changed. The new act specified that changes in primary water for TTL residents be approved by the Board of Trustees for Tribal Trust Lands (Hoffman, 1964). However, participation by 'tribal' and later communal area residents in water decision making was nil. By the Act of 1927 the priority right to water, granted to the mining industry within the Gold Belt areas, was modified in favour of irrigation (Government of Southern Rhodesia, undated). Therein were a number of clauses that disadvantaged the black population. First of all, water rights were attached to land, which disadvantaged most black Zimbabweans who had been dispossessed of land and placed in the reserves where they did not enjoy full rights. Rights to land in the reserves were registered with Communal Area bodies (formerly known as Tribal Trust Lands) and not with individuals. Natives could therefore only apply for water rights as a community, and through government officials. Even then the District Administrator or Minister of Water Development held the water right on the behalf of TTL 
residents. There was, however, provision for the appointment of representatives of "native interests' in the Irrigation Boards and in the Water Courts. Not much is known about whether or not they were actually represented. On the other hand, settlers could individually apply for water rights because they owned land in their own private capacity.

Another problem was that water rights were issued based on the priority date system; this meant that rights were granted on a first-come, first-served basis. The black indigenous people were disadvantaged because they had not applied for water rights (Derman, 1998; Manzungu, 2001). When they later understood this, most of the water was already committed to rights held by the settlers. Water rights were also issued in perpetuity, which meant that a water right once issued could not be revoked except in special circumstances, such as the declaration of a drought or when someone else applied for the same water and was willing to pay compensation. By virtue of the fact that settlers applied for the rights way before the indigenes, most of the water was committed. It should be noted that, although racial water allocation was provided for in the 1927 Water Act, it was only in the 1940s that massive transfers of water to the whites actually occurred because of cheap finance made available for both dam building and irrigation. This emphasizes the argument that it is not necessarily changes in water legislation that determine (lack of) access to water.

The 1947 Water Amendment Act had loose allowances for primary water users, especially for gardens and riparian users. The Act also defined vleis (seasonally flooded wetlands or wetlands in depressions), springs and streams that lay outside public management because they were defined as 'private water'. This changed later with restrictions on dambo (wetlands) cultivation, mainly because of fear of degradation, which had been noticed in the white farms. The Act also identified new water uses such as fish farms and conservation activities that were a result of new commercial interests.

The Water Act of 1976 upheld the principles of the 1927 Water Act, i.e. rights to water were linked to land, the priority date system of allocating water and granting a water right in perpetuity. The Act also provided for catchment outline plans to be prepared for the development and use of surface water. Three types of water were recognized: public water, private water and underground water. The Act, under a 1984 amendment, also provided for some stakeholder participation in such institutions as River Boards. The participation was, however, restricted to holders of water rights. The Act also required applicants for water rights to put in place water measuring devices for a water right to be confirmed as permanent. This explains why most water rights in the native areas were temporary - the natives could not afford to put in the requisite measuring devices.

In summary, it can be said that the system of water allocation in the colonial period was based on the matrix of ideas of efficiency and modernity and rooted overall in European power. The process was held almost entirely in male hands, with an extension of racial and patriarchal notions toward the great African majority who were denied both adequate land and water (Campbell, 2003). Campbell (2003) further argues that the settler state's planning mechanism was organized around the concept of the scarcity of water. Politicians, agricultural extension officers, water resources managers, hydrologists, engineers, planners and economists propagated the concept of water scarcity when, in reality, the problem of water availability for black Zimbabweans was distribution, not scarcity. This was reinforced by the myth that only whites could have an efficient and productive agriculture. African farmers, despite their early successes (Ranger, 1985; Phimister, 1988), were excluded from access to water.

\section{Smallholder irrigation: 1980-1997}

The legal framework that was put in place in the colonial era was by and large upheld by the new nationalist government that was elected in 1980, after 10 years of war. In the resettlement programme that was established after liberation the government supplied drinking water, but only in a few instances did it include irrigation. Irrigation systems existing on commercial farms transferred to smallholders or resettlement farmers were not maintained or protected. Another government initiative to elicit increase 
in water accessibility by reserving $10 \%$ of water in government dams was a complete failure, as no measures to make the water available were taken (IFAD, 1997). Once again, the problem was not availability of water but its delivery.

In general, government-sponsored and/or -funded irrigation schemes did not do nearly as well as expected. Several evaluation studies have suggested that smallholder irrigation schemes (initiated and constructed by the government, which may be community- or government-managed) have poor performance and are not sustainable. Problems identified include poor water utilization, in terms of its timeliness and adequacy to the field, and poor water application to the field (Pearce and Armstrong, 1990; Donkor, 1991; Makadho, 1993). Crop yields have been low and way below those achieved in the commercial farming sector. The poor agricultural performance has translated into poor financial and economic viability, thereby necessitating heavy government subsidies, up to $75 \%$ in some cases. The Rukuni Commission (Rukuni, 1994) found that the irrigation subsector in the communal and resettlement areas was dramatically underbudgeted by the state and required change. ${ }^{11}$ Pointing out the interdependency between land and water policies, the commission made a series of recommendations ${ }^{12}$ to increase the efficiency of the agriculture sector. These recommendations were neither accepted nor systematically incorporated into state policy.

The largest area under smallholder irrigation remained informal, with little or no economic support. It continues to use a mixture of indigenous and introduced technologies. This sector, estimated to cover at least 20,000 ha in the late 1990s, was said to be more productive than the formal sector (IFAD, 1997). Indigenous irrigation has therefore been undervalued to the extent that it does not feature in official statistics and policies, despite the fact that it contributes significantly to rural livelihoods and sustainable resources management. Bolding et al. (1996) have commented on the merits of indigenous irrigation. In assessing irrigation systems in the Eastern Highlands they noted why these systems were effective in contributing to food security and rural wealth. Based upon detailed empirical studies, there were several factors that led to their efficacy. These include, for example, the use of locally available materials, a norm of equity that minimized conflicts over water quantities, flexibility in adjusting to rainfall variability, fewer expenses to build and maintain and demonstrated sustainability over many years. It appears that, although this was not addressed in the original research, all those who sought irrigated land would receive some.

These local principles did not enter the central government's policy frameworks. This has meant that small-scale irrigation and local water resources management principles and practices that could have been used to support food security at the household level have not been valued or made part of government policies.

As noted previously, a different approach had been presented to the government. Of particular significance was the fact that the recommendations made by the Rukuni Commission were very much in the spirit of Article 11 of the International Covenant on Economic, Social and Cultural Rights. This emphasized the obligations to take steps to ensure the realization of the right to livelihood by 'reforming agrarian systems in such a way as to achieve the most efficient development and utilization of natural resources'. Among the Commission's recommendations to increase the efficiency of the agriculture sector, the main recommendation was increased investment in water in communal and resettlement areas. Other recommendations as to how agricultural production could be increased in communal and resettlement areas included legally secure tenure, improved credit and financial services and comprehensive agricultural support institutions. It appeared that the Zimbabwean government had little interest in smallholders. It did, however, have a new and deep interest in water management.

In the next section we turn our attention to how Zimbabwe's water reform responded to global discourse on water reform in general and how the new water policy might address small black farmer needs.

\section{Zimbabwe's 1998 Water Reform: Addressing the Colonial Legacy}

The core of Zimbabwe's water reform, initiated in the mid-1990s, rested on increasing access to water by black Zimbabweans while ensuring the productive use of water. ${ }^{13}$ New participatory 
structures were created to increase access to water management decision making. These are called Catchment and Sub-catchment Councils, and are based in Zimbabwe's seven hydrological zones. In addition, a new parastatal was established - the Zimbabwe National Water Authority (ZINWA) - to shift water management expenses from government to users and to increase the productive use of Zimbabwe's water. Prior to the Water Act of 1998, large-scale commercial farmers controlled Zimbabwe's water through a 'water rights' system - first in time, first in line. This made it very difficult for new appropriations to be made to Black small-scale farmers, who had great difficulty in finding the resources to obtain water rights and to negotiate with the bureaucracy to secure those rights.

\section{The Water Act of 1998}

Under the Act all water is vested in the President and no person can claim private ownership of any water. In presenting the first reading of the new draft Water Bill, Attorney General (now Minister of Justice) Patrick Chinamasa emphasized the following: 'What the existing legislation has done is that the water is the President's water but the President then put in legislation to give permission to people to exploit it and that is what is peculiarly known as the water right' (Zimbabwe Parliamentary Debates 1998, p. 1566).

In defending the abolition of the concept of private water, Chinamasa also asserted the common Zimbabwean understanding of water: 'Water is a public resource. It is a gift from God. None of us here are rainmakers, and that includes commercial farmers. The rainmaker is God. He provides His people and that water forms part of the hydrological cycle' (Zimbabwe Parliamentary Debates, 1998, pp. 1562-1563).

This is consistent with Zimbabwe's history as a centralized state while appearing to incorporate new global water management policies (Derman et al., 2001). The 1998 water legislation transferred most national planning functions from the Department of Water Development to the new parastatal ZINWA with oversight from the Ministry of Water Development and Rural Resources. ZINWA is funded through the sale of water collected behind government dams, the provision of water to cities and the levying of water charges to large-scale users. Management of Zimbabwe's water is to be shared with the new stakeholder organizations of Catchment Councils and Sub-catchment Councils. ${ }^{14}$

\section{Commercial and primary water: the continued colonial legacy?}

Zimbabwe's water is still divided into two categories - commercial water and primary water. Primary water is defined in the Water Act of 1998 as water used for: (i) domestic human needs in or about the area of residential premises; (ii) animal life; (iii) making of bricks for private use; and (iv) dip tanks. ${ }^{15}$ In sum, it is not restricted to drinking water but seen as an integrated part of livelihood necessities such as food and housing in the communal areas. The state is obliged to respect and protect the right to primary water as embedded in the Act. What is meant by 'domestic human needs in and about the area of residential premises' is, however, not clear. The Water Act (51.1) asserts the importance of primary water: 'No permits granted by a catchment council, other than permits for the use of water granted to a local authority for primary purposes, shall have the effect of depriving persons of the use of water for primary purposes.'

This makes provision for ensuring that primary water users will not lose any further water. However, to actualize this right means knowing how further water abstractions would affect primary users. No catchment in Zimbabwe knows the amount of primary water used because the catchment planning exercises, which were to make accurate estimates, have yet to be completed. In addition, there has been a loss of information on commercial water use. The implication that primary water use had priority over commercial water use has not been asserted to the knowledge of the authors since the implementation of the Water Act. No volumes have been provided for primary water use. While a general national estimate has been made of rural primary water use, amounting to $1 \%$ (Zimbabwe Government, 2000c), there are no detailed empirical estimates of actual use. It has been assumed that the amount of use has not justified registration in comparison with commercial water use (see below). 
New innovative forms of commercial cropping emerging within the common property regimes in the communal lands, such as gardening for consumption and sale, represent a challenge in how Catchment Councils, when issuing water permits, draw a dividing line between commercial and primary water uses. These uses render problematic the division between commercial and primary water. Under the new Water Act of 1998, it is only water used for commercial purposes that requires a permit in terms of Section 34. The definition of commercial water depends upon use - water used for purposes including agriculture, mining, livestock, hydroelectric power, etc. It follows from the ZINWA Act, Section 41, that only permitted water is subject to the user pays principle in terms of the new water levy. ${ }^{16}$ Thus rural primary water users do not have to do so.

One Catchment Council, the Mazowe, debated what constitutes the difference between commercial and primary water use. The Council Chairman suggested a technological answer: if the water is moved by hand it is primary water, if it is moved by machine then it will be considered commercial. The Catchment Manager from ZINWA present at the meeting indicated that, as yet, ZINWA had not decided what the guidelines should be in deciding whether water use was primary or commercial. ${ }^{17}$ Villagers from Bangira, in Mhondoro Communal Lands, who argued that they would refuse to pay for water moved by a pump to provide their vegetable gardens with water, contested this view. A couple who had worked hard to establish funding for the local dam in order to raise their living standards and those of other families argued that, since the surplus from the gardens was used for livelihood essentials such as clothes, school fees or medicine, the water use should not be seen as commercial.

Research investigating different catchment councils demonstrates that the intention of the new Water Act to 'ensure that the availability of water to all citizens for primary purposes' was not realized (Derman, et al., 2001; Dube and Swatuk, 2002; Mtisi and Nicol, 2003; Manzungu, 2004b). Indeed, the emphasis was upon catchments and sub-catchments to raise revenue for them and for ZINWA. In the Mzingwane catchment, which had limited commercial water to levy, there was a suggestion of levying a charge for every herd of cattle. In the Save Catchment levies were proposed for any water use where some income was realized.

This lack of conceptual and policy clarity also applies to the thousands of boreholes currently used in Zimbabwe. ZINWA's policy was to register all boreholes and then charge borehole owners for water because, like all water, it belongs to the government. On the other hand, the Presidential Land Review Committee under the Chairmanship of $\mathrm{Dr}$ Charles Utete recommended that levying water from boreholes should be stopped because it discourages investment in water resource development and the enhancement of production on farms through irrigation' (Utete, 2003, vol. 1, p. 177). No attention was paid in this report to the scale and intensity of borehole water use.

\section{The Water Act and human rights}

These different conceptualizations do not sit well with the definition of water of the Committee on Economic and Social, and Cultural Rights as a part of the right to livelihood as stated in General Recommendation 15. This recommendation emphasizes that the sustainable access to water resources for agriculture is necessary to realize the right to adequate food. Local management systems as described earlier cut across the commercial/ primary division. In our view, an approach based on human rights calls for a clearer definition of primary water uses that transcends clean drinking water and includes the legitimate concerns of poor small-scale farmers. While such legal clarifications may be undertaken by the stroke of the pen, the CESCR also obliges states to take positive steps to fulfil the human right to water. Such positive steps call for longterm economic commitments, implying that internal and external economic resources invested in infrastructure are beneficial for the poor in all of Zimbabwe's rural areas, not just in the newly resettled ones. ${ }^{18}$

Despite the emphasis on equality of access in the initial phases of water reform, most attention has been devoted to increasing the number of commercial water users. Zimbabwe's new water management system was based on the premise that fees for commercial water use 
would be used for the development of water resources. The areas under irrigation in Zimbabwe have diminished greatly, since the irrigation systems on the former commercial farms have not been sustained and older government-sponsored irrigation schemes have been unable to continue in light of the harsh macro-economic climate following the fasttrack land reform. According to Manzungu (Utete Report, 2003, Vol. 2, p. 89) the total number of hectares under irrigation has fallen from 186,600 to 120,410 . This loss of 66,000 ha under irrigation has primarily been in the formerly large-scale commercial farm sector.

The institutional separation of water supply through Rural District Councils from water resources management issues through Catchment Councils in the communal lands is another factor that has inhibited water development. Under the water reform, Catchment and Sub-catchment Councils had reasonable sources of funding where Rural District Councils are underfunded and have too many obligations. Questions of water supply are also linked to borehole provision for combined domestic and productive use, especially in the communal and resettlement areas. Under the new water policy, the Integrated Rural Water Supply and Sanitation Program remains separate from the above while continuing to be tasked with providing safe, protected drinking water supplies for all rural water users and to ensure that every household had at least an improved, partially enclosed latrine. This separation has tended to alienate primary water users, who are the vast majority of Zimbabwe's water users (Manzungu, 2004a, p. 13).

Water supply programmes have been especially vulnerable to government service shrinkage and donor withdrawal. It is poorer women who rely heavily on water sources that are free of charge, such as borehole water for their gardens, and who find themselves caught in the gaps and mismatches between these different policies and institutional structures. Their water needs fall outside the scope of both the water and sanitation programme and the water reform policy aimed at larger-scale users. In our view, better coordination and linkages between Catchment and Sub-catchment Councils with Rural District Councils would have been a better strategy, although admittedly difficult. The involvement of both water institutions could have provided appropriate incentives for the participation of small-scale users.

The new Zimbabwean water policy seeks to have a single uniform water management system in place. The regulations framing the new water management system are, by and large, moulded on a large-scale commercial farming model giving little attention to the potential of local irrigation systems and methods developed by communal-area farmers. Local irrigation methods and principles as described above and analysed in the natural resources management literature have not entered the central government's policy frameworks (Bolding et al., 1996). This has meant that small-scale irrigation and local water resources principles and practices that could have been used to support food security at the household level have not been valued or made part of government policies.

In communal areas and resettlement schemes both men's and women's access to water still rely heavily on use rights embedded in local norms and practices (Pinstrup-Andersen, 2000, p. 13). These local use rights have, in part, been protected, as described above, by the concept of primary water. In the next section we explore whether there might be an explicit or implicit recognition of 'a right to livelihood', at least with respect to access to water for livelihood purposes in Zimbabwe's rural areas.

\section{A Rights Perspective on Water and Livelihood}

Derman, Hellum and Sithole have, since 1999, been studying water management in the three villages of Bangira, Murombedzi and Kaondera in the chieftainship of Mashamayombe in Mhondoro Communal Land (Derman and Hellum, 2003; Hellum and Derman, 2005). ${ }^{19}$ This local qualitative study was part of a wider study of national water reform in Zimbabwe that was undertaken by the Center for Applied Social Studies (CASS) at the University of Zimbabwe. We chose this area due to a rapid and recent increase in tobacco growing, a relatively large number of private wells and the existence of a dam project. Apart from dry-season vegetable gardens located along streams, rivers, 
vleis and boreholes, agriculture in this area remains primarily rain-fed maize with an expansion of irrigated tobacco. Because of these trends in commercialization, we expected to find a decreasing open access to the area's water resources. We made the assumption that, because the deep and open wells were located on homesteads and that there was a great increase in tobacco production, that these wells would become increasingly 'private'.

\section{Water for life: the right to safe drinking water}

Our study in Mhondoro suggested that at the local level, as in human rights law, there is a right to clean drinking water. Villagers demonstrated a surprising degree of consistency over time and space in upholding the norm that no one can be denied clean drinking water (Derman and Hellum, 2003). The obligation to share drinking water extended to wells, which were privately dug, and on basically private land. In one village a private borehole, paid for by one household, rapidly became a village source of drinking water. In another village a borehole built by the Zimbabwe Tobacco Association for irrigating tobacco seedlings became an important drinking source for the entire village. In a third village in the study area, the private well of a widow served as a source of drinking water for almost the entire village.

Based on the norm and practice of sharing, access to drinking water extended to boreholes constructed for principally commercial, dedicated or private use. The duty to share increased rather than decreased during drought periods. Such sharing cut across kinship and village borders, and it has been upheld during the accelerating economic and political crisis. Water users and well owners reported that they had never paid or received money or given gifts. To breach the norm of providing drinking water meant risking sanctions or being the target of witchcraft. ${ }^{20}$ Universal access to drinking water in Mhondoro points to a morally based duty rather than a negotiable and reciprocity-based notion of property, often pointed to as a characteristic feature of African customary laws (Berry, 1993). ${ }^{21}$ Applicable to men and women, insiders and outsiders, it also points to a notion of equality and non-discrimination.
These findings are consistent with our readings of a series of Zimbabwean monographs on natural resources management including water, wetlands, forests and land (Cleaver, 1995; Derman, 1998; Sithole, 1999; Matondi, 2001; Nemarundwe, 2003; Walker, undated, unpublished paper). All the empirical records from communal areas in Shamva, Mutoko, Chiduku, Dande, Masvingo, Guruve and Matabeleland suggest that water for drinking can, and should, be made available to all. Nemarundwe, in her doctoral thesis, reports from the Romwe catchment in the Chivi district, South Zimbabwe that drinking water is made available to all no matter what the source of water is. Available water sources include boreholes, river bed wells, rivers, wells, collector wells and dams. No matter the tenurial status, whether publicly or privately owned, the water sources are available for drinking water. In a powerful and clear manner she writes: 'Because water is considered hupenyu (life), there has been no case of denying another village access to water during drought, although rules of use are enforced more stringently during drought periods' (Nemarundwe, 2003, p. 108).

The study points to actual incidents where this general ideal was challenged. One example is a well owner who prevented others from accessing his well. Two days after he locked the gate to the well he found a dead dog. In response to this the well owner later unlocked the gate (Nemarundwe, 2003, p. 113). In a similar vein Prosper Matondi, who carried out his research in an area of resettlement farmers and two irrigation schemes in the Shamva district near Bindura, the provincial capital of Central Mashonaland Province, found that drinking water remained available for all despite growing scarcity of both land and water resources. In a parallel fashion, Bevlyne Sithole's research in Mutoko and Chiduku communal areas in eastern Mashonaland and Manicaland Provinces, respectively, summarizes farmers' views on water as follows: 'Water should be available to all, rich or poor, but the person who impounds the water is the one who makes the river dry' (Sithole, 1999, p. 195). Frances Cleaver's study in the Nkayi communal land in Matabeleland suggests that water user rules that limit poor people's access to water are invalid. She observed that poor women got 
away with breaking the rules that limited water resource to certain individual users (Cleaver, 1995, p. 357).

\section{Water for livelihood: the right to garden?}

Rural people in Zimbabwe see land and water as closely interconnected in fulfilment of livelihood needs. Livelihoods are no longer just about access and use of land and water in rural areas. ${ }^{22}$ Access to basic livelihood resources such as health services, food and housing also depends on cash. Like many rural southern African residents, Zimbabweans are dependent upon remittances from kin in cities or abroad, or reliant upon their own engagement with paid jobs or market activities. Households and families are quite different and even in one rural area there are significant differences between them in terms of reliance upon land and water. Yet, within the context of this mixed rural livelihood structure, dambo cultivation has particular significance since wetlands have grown in importance due to the unpredictability of Zimbabwe's rains, increased reliance upon cash crops and the possibilities of hand irrigation.

Almost every family in the three villages in Mhondoro had gardens when we began our study in 1999. A quantitative survey of water management in the area demonstrated that $90 \%$ of households had some form of dryseason garden requiring hand irrigation. ${ }^{23}$ The larger and more productive gardens tended to be close to, or in, wetlands, but there were significant gardens at the homestead if there was a borehole or productive well close at hand.

The family gardens were usually the main responsibility of the women. The crops in the gardens are covo, rape, onions, tomatoes, beans, groundnuts, maize, sugarcane and cabbage. There are also fruit trees including banana, papaya and mango. These rely heavily on the common pool water resources including rivers, boreholes, deep wells and shallow wells. Gardens are often situated on land that is either seasonally flooded or holds water from the rainy season long into the dry season. The gardens are as much a source of income as of food for the family. The income is often used for meeting household needs including food, education, clothing and medicine. In the recent years of drought and economic hardship, the produce from women's gardens has been an essential source of livelihood.

Dambo cultivation in Mutoko and Chiduku in eastern Mashonaland and Manicaland coincided with the establishment of mission schools and hospitals in the mid-20th century (Sithole, 1999, p. 140). ${ }^{24}$ As in Mhondoro, the major garden crops came first from large-scale commercial farms and then from agricultural extension officers during and after the colonial period. Three Mhondoro elders told us they were the first villagers to start gardening in the 1950s. They were taught to grow vegetables by an agricultural extension officer in the colonial administration. Women especially expanded their gardens after independence to provide green vegetables for their families. Gardening increased in the 1990s as the rate of inflation rose. Government construction of boreholes, cement wells and some small dams facilitated further garden expansion. The Zimbabwean government began withdrawing from rural areas during the 1990s under the combined policies of structural adjustment and decentralization. People in Mhondoro, as local communities elsewhere, have since been left to find alternative economic sources for expanding water supply for drinking water, watering cattle and irrigation. The CASS survey indicated that more than $70 \%$ of the households in the three villages had invested work and money in water, including private wells and other water resources.

The mixed character of the principles that derive from this agricultural practice is neither traditional nor modern, demonstrating that rural people in their livelihood strategies draw on a wide variety of sources. Our study of gardens in Mhondoro suggests that the right to water as part and parcel of rural livelihoods extends beyond the right to clean drinking water (Hellum, 2007). Households that needed garden lands were allocated appropriate land. ${ }^{25}$ Everyone we interviewed in one village stated they had obtained the headman's explicit or implicit approval to access land for gardens on vleis or close to rivers. The gardens, the Sabhuku (village headman) said, were important sources of livelihood and self-reliance. For this reason he had not taken action when 
people allocated themselves gardens without his permission. Another reason was fear of revenge from ngozi (bad spirits). This suggests the existence of an underlying norm of sharing. A similar pattern was observed in another village, where people's gardens were moved from the wetlands to communal gardens close to a newly constructed dam. Everyone was granted land for gardens in this area. If the land allocated for the communal gardens was insufficient, the headman saw it as his duty to allocate more land. None of the villagers we interviewed had paid for the land. This suggests a wider right to livelihood that is not limited to clean drinking water, but extends to access to garden lands with available water sources.

The right to use available water for gardens, however, appears to be subject to greater contestation than a right to drinking water. For example, Nemarundwe (2003) provides a short illustrative case of water conflict at a small dam between richer and poorer, women and men and livestock owners and non-livestock owners. During a drought year the dam committee chairman sought to stop villagers from planting gardens until it was clear that there was enough water for livestock. Garden project members protested, indicating that such a move would disadvantage poor farmers who, after all, did not own livestock and depended on the irrigated plots for their livelihoods (Nemarundwe, 2003, p. 166). The dam chairman proceeded to seal off (with the assistance of two other villagers) all outlet valves at the dam so that no water could flow to the gardens. As a result, villagers challenged him publicly. The dam chairman then let out all the water, until it was below the outlets. The resolution of disputes required external authorities to help sort out the conflict. The dam chairman was subject to a tribunal organized by the Rural District Council and the NGO supporting the project. He was reprimanded and the villagers called for him to resign from the dam committee. However, he apologized to the project members and promised to cooperate with other farmers in conserving water resources.

Our reading of Sithole and Matondi suggests that, unlike the right to safe drinking water, the right to garden lands with available water was, in the final analysis, limited to kin. Prosper Matondi's study from Shamva focused on the growing scarcity of arable land near water (Matondi, 2001). As is the case throughout Zimbabwe, dambo gardens are located near the streams dissecting the vleis that are also used as grazing areas. However, over time they have been used more for gardens than for grazing. With the presence of livestock, gardens have to be fenced to prevent animals from eating the produce and drinking from the well. The fencing of vegetable gardens along rivers or on wetlands is common practice all over Zimbabwe. This suggests that, once the land is allocated for gardening, the land and the water available for irrigation become family property. Access to both land and water thus may be restricted on the basis of kinship ties. In the same vein, Sithole (1999) documents increased desiccation of dambo areas in Mutoko (Mashonaland East Province) and Chiduku (Manicaland Province) communal areas, and thus increased difficulties in using the water from dambos for small-scale irrigation.

The main mechanism for sharing scarce livelihood resources under these conditions is subdividing the land among kin within the broader family. This suggests that, in situations of scarcity of common pool resources, the norm of sharing is placed on the kin. Often, this scarcity has been created by the unequal divisions between land and water and between the commercial farm sector and the communal and resettlement areas. The pattern was that rather than deny some families or households access to dambo land, the gardens were subdivided into smaller areas. It remains to be seen whether this situation has been altered by the Fast Track Land Reform.

While access to gardens with available water resonates with villagers' deep concern for livelihood it is, unlike the right to safe drinking water, not available on a universal and non-discriminatory basis. Outsiders do not have access and the land is, in principle, allocated to the male head of the household on behalf of the family. Yet livelihood concerns crosscut the male status rule so as to make land available to single and childless women, widows and divorcees. While married women, due to these formalities, have been seen as landless, Sithole (1999, p. 80) observed that women seem to be acknowledged by most men as owners of the garden. ${ }^{26}$ This strongly suggests that ownership within the 
family is not acquired through rules concerning family representation but by actual use and work on the land.

While accepted within and amongst local communities, these norms are frequently overlooked and disregarded in development policies, projects and practices. In one of the largest resettlement projects in a communal area in the Zambezi valley, Derman (1997) reports that women farmers could no longer maintain their dambo gardens since they were moved away from streams and rivers. Boreholes were provided for drinking water and watering livestock. There was no broader concern for livelihood as people were left to dig their own garden wells to supply water for vegetables. Some women continued walking long distances to keep up their gardens, while other families invested in private wells. For many women the only solution was to use the scarce borehole water for irrigating vegetables. Because of the very dry conditions and livestock water requirements there is great pressure upon the functioning boreholes which, in turn, has meant that many women have had to give up or reduce their gardens.

\section{Conclusions and Reflections on the Right to Water and Livelihood}

In sum, these practices from different parts of Zimbabwe point toward the existence of a set of interrelated norms of sharing of land and water that are essential for livelihood. Both clean drinking water and access to land with available water are shared between and within village households on a day-to-day basis. This norm underlies trouble-free cases (cases where agreement is reached through everyday practice without involvement in any dispute resolution), but it is also confirmed by ideal statements from villagers (what people say) and, more importantly, by trouble cases from Nemarundwe's, Sithole's, Matondi's and our own research. However, three interrelated processes threaten these norms and practices: (i) the broad economic and social crises that have coincided with the Fast Track Land Reform and have altered the rural landscapes; (ii) the fiscal crises of ZINWA and Catchment Councils, leading them to want to increase their sources of water revenues; and (iii) pressures upon water resources due to drought or conflicts over use between mining or livestock and gardens.

The widespread acceptance of these norms emerges as vital in the ways that local communities handle poverty and food security. These local norms and practices interconnect with emerging human rights law that considers water as part of the right to livelihood. This includes clean drinking water and adequate access to water for subsistence farming and for securing livelihoods. The current multi-level and multilayered political and economic crises in Zimbabwe pose challenges to the use of human rights as a framework for reform. Because international human rights are considered to be incompatible with the current Africanist directions of the Government of Zimbabwe, the Covenant on Economic, Social and Cultural Rights, the Convention on the Rights of the Child and the Protocol to the African Charter on the Rights of Women (among others) have been deemed irrelevant to the government's policies. Our research suggests that this dichotomous perception of African culture and human rights is false insofar as the rights to water and livelihood are concerned. It shows that prevailing norms and practices in communal areas and the emerging human right to water and livelihood provide common ground for a new framework facilitating active and direct support to small-scale (and often poor) farmers.

Primary water can be a starting point for national legislation and policies to include a 'right to water' and a 'right to livelihood'. The idea of a priority right to primary water for basic human needs, including domestic, animal and housebuilding functions, is unique in the region. It has meant that such water in principle has been protected from the growing demand for 'user pay' which, according to the Water Act, is restricted to commercial water. However, the pressure upon a more privatized water sector, led by the Zimbabwe National Water Authority, to be self-financing in the context of a national economic crisis demonstrates the need for greater legal and political clarity for primary water. Indeed, the 'goal' of water reform appears to be increasing the amount of water that can be labelled 'commercial' rather than 'primary'.

In our view, then, priority could focus on how to use primary water for socially beneficial 
and development purposes other than simply expanding commercial water use. Primary water enables the concept to be developed in the light of local concerns and the wider regional and international human rights laws. However, we do not think under current circumstances that Zimbabwe can, in practice, achieve the broadening of such rights. Rather, given the growing scarcity of resources we can easily envision ZINWA or Catchment Councils whose members are attempting to obtain revenues by defining these small gardens as commercial ventures, in which case they will be said to be using agricultural water, which attracts a price.

Another related problem is where Catchment Councils label all water as stored, which attracts a higher price compared with what is called normal flow. Basically, this means that smallholder farmers will, in principle, have to pay for the irrigation water. Once again, rural people's decision making seems highly responsive and sensible in the light of changing survival requirements and should guide laws and policies. A better approach would be to assist smallholders to increase their use of water and therefore production, with the likelihood of increased nutrition and decreased illness, especially if sanitation is improved simultaneously.

Local discourses and practices of distribution and management of water speak of the emerging notion of water as a human right. Older dambo cultivation and more recent gardens have been utilized under a principle of a right of access to both land and water for livelihood purposes. The concept of livelihood, as locally understood, has responded to a changing social and economic environment by including sale of produce but with the understanding that it is for socially understood purposes, including education of children, health expenses, clothing, house repair, etc., along with the consumption of garden products. It cuts across a narrow distinction between commercial and primary water. From the perspective of a local livelihood, it makes little sense to make a distinction between garden products that are directly consumed by the family and products that are sold to provide for medicine, food or clothes.

Neither the Zimbabwean land reform nor the water reform addresses how to assist those engaged in small-scale irrigation. The priority has been given to commercial water and to redeveloping irrigation systems in what had been the large-scale commercial farming sector. In Zimbabwe, most communal area irrigation is outside of formal irrigation schemes. Neither the Zimbabwe water acts nor recent policy documents make any mention of how to support informal irrigation carried out in Zimbabwe's communal areas and, increasingly, in the former commercial farmlands. This has to do with the division between the development functions for communal and resettlement areas tasked to Rural District Councils and central government, water management functions given to Catchment Councils, ZINWA and the Ministry of Water Development and the rural water-supply functions that are separate from the new institutions of water reform.

Lastly, given the importance of women, a grounded human rights analysis would greatly strengthen efforts to identify potential discriminatory effects and to suggest policies to increase women's production. One problem is that water sources used by female small farmers, for example irrigation of vegetable gardens by borehole water, have been seen by conventional economic standards as unproductive. As a result of the gendered character of land and water uses, seemingly gender-neutral investment policies have often disproportionately favoured expensive water supply services controlled by men. This may lead to indirect discrimination, in terms of both CEDAW and the Protocol of the Rights of Women to the African Charter.

\section{Acknowledgements}

Drs Manzungu and Machiridza would like to thank the Challenge Programme, Project Number 47: 'Transboundary water governance for agricultural and economic growth and improved livelihoods in the Limpopo and Volta basins - towards African indigenous models of governance', without whose financial support the writing of this paper would not have been possible. Bill Derman was supported in his research by a Fulbright-Hays Research Grant, a Wenner-Gren Foundation Grant for Anthropological Research and the BASIS CRSP 
for Water and Land Research in Southern Africa. Anne Hellum has been supported by the Ministry of Foreign Affairs/Norwegian Research Council Program Development Grant for the Institute of Women's Law at the Faculty of Law, University of Oslo and the NORAD-funded cooperation between the Institute of Women's Law (University of Oslo) and the Southern and Eastern African Center of Women's Law (SEACWL) at the University of Zimbabwe. Mr Pinimidzai Sithole's research has been supported by the BASIS Mentors' Program and the BASIS CRSP for Water and Land Research in Southern Africa.

\section{Endnotes}

1 In general, Conventions are instruments passed by the UN General Assembly. Conventions are made binding for state parties by ratification. Two conventions are formally termed covenants. These are the Covenant on Civil and Political Rights, 1966 and the Covenant on Social, Economic and Cultural Rights, 1966. General recommendations/general comments are the interpretations of the human rights treaty bodies that, in accordance with the respective conventions, have the power to make such recommendations. The general recommendations are not directly binding for the state parties to the conventions, like the conventions themselves. They are sources of interpretation accorded weight by international and national courts.

2 The four Dublin Principles are: (i) fresh water is a finite and vulnerable resource, essential to sustain life; (ii) water is an economic and social good; (iii) water development and management should be based on a participatory approach involving users, planners and policy makers at all levels; and (iv) women play a central part in the provision, management and safeguarding of water. The thinking behind these principles has been incorporated into policy documents authored by the World Bank and other donor organizations (World Bank, 1993, 2002, 2003a, b).

3 Southern African rural scholarship and practice have focused upon livelihood strategies, access to resources and the necessary institutional changes to support rural livelihoods. See for example Scoones, 1996; Sithole, 1999; Benjaminsen et al., 2002; Nemarundwe, 2003.

4 Water reform has been part of the general process of decentralization. The argument runs that, if natural resources are managed at the local level, then they will be looked after better and more efficiently, resulting in improved opportunities for sustainable livelihoods (SLSA Team, 2003a, p. 3). There was, however, no discussion of the local practices and norms that can influence or even determine whether decentralization will be successful.

5 There continues to be an important debate about the origins of fast track and its relationship to the parliamentary elections of 2000. One line of thinking views the land invasions as politically motivated to win the elections (Sachikonye, 2003, 2005; Hellum and Derman, 2004, among others), while the other perspective contends that fast track was an unplanned response to pressures from landless people (Moyo and Yeros, 2005).

6 In Africa, the right to water had been incorporated into national instruments in the region. For example, the right to water is embedded in the Bill of Rights in Section 27 (1) (b) of the South African Constitution. It states that everyone has the right to have access to sufficient water. Article 12 of the Zambian Constitution maintains that the state shall endeavour to provide clean and safe water. According to Article 90 of the Ethiopian Constitution, every Ethiopian is entitled, within the country's resources, to clean water. The preamble to the Namibian Sixth Draft Water Resources Management Bill of 2001 states that the government has overall responsibility for and authority over the nation's water resources and their use, including equitable allocation of water to ensure the right of all citizens to sufficient safe water for a healthy and productive life and the redistribution of water.

7 The Protocol was adopted by the 2nd Ordinary Assembly of the African Union, Maputo, 11 July 2003 and entered into force in 2006.

8 The statement of understanding states that: 'In determining vital human needs in the event of conflicts over the use of water courses, special attention is to be paid to providing sufficient water to sustain human life, including both drinking water and water required for production of food in order to prevent starvation.'

9 The introduction to the Protocol states that Articles 60 and 61 of the African Charter on Human and Peoples' Rights recognize regional and international human rights instruments and African practices consistent with international norms on human and people's rights as being important reference points for the application and interpretation of the African Charter.

10 This obligation is embedded in Article 1 of the CEDAW and in Article 2 in the Protocol to the African Charter on the Rights of Women.

11 The Commission of Enquiry into Appropriate Agricultural Land Tenure Systems (referred to as the Rukuni Commission 1994). 
12 Recommendations 8.8.1, 8.8.3, 8.8.4 and 8.8.5, Rukuni Commission (1994).

13 There is a substantial literature on different dimensions of Zimbabwe's water policies and water reform, including Derman et al., 2001; Dube and Swatuk, 2002; Derman and Gonese, 2003; Mtisi and Nicol, 2003; Bolding et al., 2004; Hellum and Derman, 2005, among others.

14 These are the Sanyati, Manyame, Mazowe, Save, Runde, Mzingwane and Gwayi.

15 Water Act 1998 section 32 (1).

16 In accordance with section 41 in the ZINWA Act, the Minister may, in consultation with the approval of the Minister responsible for finance, by statutory instrument, impose a water levy on any person holding a permit issued in terms of the Water Act (Chapter 20, p. 24).

17 Derman Research Notes, February 2000. At a Mazowe Catchment Council meeting there was a discussion on whether to ask the Centre for Applied Social Sciences to suggest a definition for commercial water. This discussion ended when the Council's Chair suggested the technological definition.

18 There has been a large decline in support to communal areas due to the emphasis upon land acquired during the Fast Track Land Resettlement Programme.

19 Mhondoro Communal Land is situated in the Chegutu district, which is made up of commercial farm, small-scale commercial, communal, resettlement and urban areas $120 \mathrm{~km}$ west of Harare. The major river that flows through this high plateau area is known as the Mupfure. It is part of the larger Sanyati River Catchment south-east of Harare and flows through communal and commercial land, including the city of Chegutu.

20 The norms of sharing and potential sanctions exist in those areas of the three catchments where the CASS water research team has been working.

21 There is an intense debate on the degree and extent to which access to land can be obtained through kin ties and networks and the extent to which it is being concentrated and access controlled by an emergent property class (Berry, 2002; Peters, 2004). Increasing land concentration and control will have significant consequences for access to water.

22 The process of decreasing dependence upon agriculture alone has been called de-agrarianization by Deborah Bryceson, 1999.

23 CASS BASIS survey data, CASS 2000-2001.

24 As noted earlier, dambo or wetlands cultivation is quite old, but dry-season gardens are recent.

25 'Informal irrigation' land constitutes the vast majority of irrigated lands in Zimbabwe's communal areas. Yet the Irrigation Strategy of 1994, which was carried out in preparation for water reform, focused only on government-sponsored formal irrigation schemes that comprised only 2000 ha at that time (Zimbabwe Government, 1994).

26 This is not straightforward. Sithole (1999, p. 80) writes: 'It seemed impossible for women and men for that matter to think about ownership in terms of this belonging to this one or that one.'

\section{References}

Benjaminsen, T., Cousins, B. and Thompson, L. (eds) (2002) Contested Resources: Challenges to the Governance of Natural Resources in Southern Africa. Programme for Land and Agrarian Studies, University of the Western Cape, Cape Town, South Africa.

Berry, S. (1993) No Condition Is Permanent: the Social Dynamics of Agrarian Change in Sub-Saharan Africa. University of Wisconsin Press, Madison, Wisconsin.

Berry, S. (2002) Debating the land question in Africa. Comparative Studies in Society and History 44 (4), 638-668.

Bolding, A., Manzungu, E. and van der Zaag, P. (1996) Farmer-initiated irrigation furrows: observations from the Eastern Highlands. In: Manzungu, E. and van der Zaag, P. (eds) The Practice of Smallholder Irrigation: Case Studies from Zimbabwe. University of Zimbabwe, Harare, Zimbabwe, pp. 191-218.

Bolding, A., Manzungu, E. and Zawe, C. (2004) Irrigation policy discourse and practice: two cases of irrigation transfer in Zimbabwe. In: Mollinga, P. and Bolding, A. (eds) The Politics of Irrigation Reform: Contested Policy Formulation in Asia, Africa and Latin America. Ashgate, Aldershot, UK, pp. 166-206.

Bryceson, D. (1999) Sub-Saharan Africa Betwixt and Between: Rural Livelihood Practices and Policies. Working Paper 43, African Studies Center, Leiden, Netherlands.

Campbell, H. (2003) Reclaiming Zimbabwe: the Exhaustion of the Patriarchal Model of Liberation. David Philip Publishers, Johannesburg, South Africa.

Central Statistical Office (2002) Preliminary Report, National 2002 Population Census. Government Printers, Harare, Zimbabwe. 
Chakaodza, A.M. (1993) Structural Adjustment in Zambia and Zimbabwe: Reconstructive or Destructive? Third World Publishing House, Harare, Zimbabwe.

Chidenga, E.E. (2003) Leveraging water delivery: irrigation technology choices and operations and maintenance in smallholder systems in Zimbabwe. PhD thesis, Wageningen University, Wageningen, Netherlands.

Cleaver, F. (1995) Water as a weapon: the history of water supply development in Nkayi District, Zimbabwe. In: Grove, R. and McGregor, J. (eds) Environment and History Journal: Special Issue Zimbabwe 1 (3), 313-333. The White Horse Press, Cambridge, UK.

Derman, B. (1997) How green was my valley! Land use and economic development in the Zambezi valley, Zimbabwe. In: Isaac, B. (ed.) Research in Economic Anthropology 18, 331-380. Greenwood, Greenwich, Connecticut.

Derman, B. (1998) Balancing the waters: development and hydropolitics in contemporary Zimbabwe. In: Donahue, J. and Johnston, B. (eds) Water, Culture and Power. Island Press, New York, pp. 73-94.

Derman, B. and Gonese, F. (2003) Water reform: its multiple interfaces with land reform and resettlement. In: Roth, M. and Gonese, F. (eds) Delivering Land and Securing Livelihood: Post-Independence Land Reform and Resettlement in Zimbabwe. Centre for Applied Social Sciences, University of Zimbabwe, Harare and Land Tenure Center, University of Wisconsin, Madison, Wisconsin, pp. 287-307.

Derman, B. and Hellum, A. (2003) Neither tragedy nor enclosure: are there inherent human rights in water management in Zimbabwe's communal lands? In: Benjaminsen, T. and Lund, C. (eds) Securing Land Rights in Africa. Frank Cass, London, pp. 31-50.

Derman, B. and Hellum, A. (2007) Land, identity and violence in Zimbabwe. In: Derman, B., Odgaard, R. and Sjaastad, E. (eds) Citizenship and Identity: Conflicts over Land and Water in Contemporary Africa. James Currey, London.

Derman, B., Gonese, F. and Ferguson, A. (2001) Decentralization, Devolution and Development: Reflections on the Water Reform Process in Zimbabwe. Centre for Applied Social Sciences, University of Zimbabwe, Harare, Zimbabwe.

Dube, D. and Swatuk, L. (2002) Stakeholder participation in the new water management approach: a case study of the save catchment, Zimbabwe. Physics and Chemistry of the Earth 27, 867-874.

Eide, A. (2001) The right to an adequate standard of living including the right to food. In: Eide, A., Krause, A. and Rosas, A. (eds) Economic, Social and Cultural Rights: a Text-Book. Kluwer International, Dordrecht, Netherlands.

Government of Southern Rhodesia (undated) Water Act of 1927. National Archives of Zimbabwe, Harare, Zimbabwe.

Hammar, A., Raftopolous, B. and Jensen, S. (2003) Zimbabwe's Unfinished Business. Rethinking Land, State and Nation in the Context of Crisis. Weaver Press, Harare, Zimbabwe.

Hellum, A. (2001) Towards a human rights based development approach: the case of women in the water reform process in Zimbabwe. Law, Social Justice and Global Development, University of Warwick Online Journal. Available at http://elj.warwick.ac/uk/global/issue/2001-1/hellum.html

Hellum, A. (2007) Human rights encountering gendered land and water uses: family gardens and the rights to water in Mhondoro Communal Land. In: Hellum, A., Stewardt, J., Ali, S. and Tsanga, A. (eds) Human Rights: Gendered Women's Realities and Plural Legalities. Weaver Press, Harare, Zimbabwe.

Hellum, A. and Derman, B. (2004) Land reform and human rights in contemporary Zimbabwe: balancing individual and social justice through an integrated human rights framework. World Development 32 (10), 1785-1805.

Hellum, A. and Derman, B. (2005) Negotiating water rights in the context of a new political and legal landscape in Zimbabwe. In: von Benda-Beckmann, F., von Benda-Beckmann, K. and Griffiths, A. (eds) Mobile People, Mobile Law: Expanding Legal Relations in a Contracting World. Ashgate, Aldershot, UK and Burlington, Vermont, pp. 177-198.

Herbst, J. (1990) State Politics in Zimbabwe. University of Zimbabwe Publications, Zimbabwe and University of California Press, Berkeley, California.

Hoffman, H.J. (1964) Water Law in South Rhodesia. The Government Printer, Salisbury, Rhodesia.

IFAD (International Fund for Agricultural Development) (1997) Smallholder Irrigation Support Programme. Formulation Report, Harare, Zimbabwe.

Kujinga, K. (2002) Decentralising water management: an analysis of stakeholder participation in the management of water in Odzi subcatchment area, Save Catchment. In: Jonker, L., Beukman, R., Nyabeze, W.R., Kansiime, F. and Kgarebe, B.V. (eds) Integrated Water Resources Management: Theory, Practice, Cases. Journal of Physics and Chemistry of the Earth 27 (11-22), 897-905, Pergamon Press, UK/USA. 
Kujinga, K. and Manzungu, E. (2004) Enduring contestations: stakeholder strategic action in water resource management in the Save Catchment Area, eastern Zimbabwe. Eastern Africa Social Science Research Review 20 (1), 67-91.

Makadho, J.M. (1993) An approach to quantifying irrigation water delivery performance. Paper presented at the University of Zimbabwe/AGRITEX/IFPRI workshop: 'Irrigation Performance in Zimbabwe, Juliasdale, Zimbabwe, 4-6 August 1993.

Makarau, A. (1999) Zimbabwe's climate: past, present and future. In: Senzanje, A., Manzungu, E. and van der Zaag, P. (eds) Water for Agriculture in Zimbabwe: Policy and Management Options for the Smallholder Sector. University of Zimbabwe Publications, Harare, Zimbabwe, pp. 3-16.

Manzungu, E. (1999) Strategies of smallholder irrigation management in Zimbabwe. PhD thesis, Wageningen University, Wageningen, Netherlands.

Manzungu, E. (2001) A lost opportunity: the case of the water reform debate in the Fourth Parliament of Zimbabwe. Zambezia XXVIII (i), Zimbabwe.

Manzungu, E. (2002) Global rhetoric and local realities: the case of Zimbabwe's water reform. In: Chikowore, G., Manzungu, E., Mushayavanhu, D. and Shoko, D. (eds) Managing Common Property in an Age of Globalisation: Zimbabwean Experiences. Weaver Press, Harare, Zimbabwe, pp. 31-44.

Manzungu, E. (2003) Of science and livelihoods strategies: two sides of the commercialization debate in smallholder irrigation schemes. In: Bolding, A., Mutimba, J. and van der Zaag, P. (eds) Interventions in Smallholder Agriculture: Implications For Extension in Zimbabwe. University of Zimbabwe Publications, Harare, Zimbabwe, pp. 110-130.

Manzungu, E. (2004a) Water for All: Improving Water Resource Governance in Southern Africa. Gatekeeper Series No. 113, International Institute for Environment and Development (IIED), London.

Manzungu, E. (2004b). Public institutions in smallholder irrigation in Zimbabwe. In: Moll, H.A.J., Leeuwis, C., Manzungu, E. and Vincent, J. (eds) Agrarian Institutions between Policies and Local Action: Experiences from Zimbabwe. Weaver Press, Harare, Zimbabwe.

Manzungu, E. and Kujinga, K. (2004) Enduring contests: Stakeholder strategic action in water resource management in Save Catchment Area, Eastern Zimbabwe. Eastern Africa Social Science Research Review XX (1) (2004), 67-92.

Manzungu, E. and Senzanje, A. (1996) A political-economy approach to water reform in Zimbabwe's agricultural sector. Paper presented at the University of Zimbabwe/ZIMWESI Workshop: 'Water for Agriculture: Current Practices and Future Prospects', Mandel Training Centre, Marlborough, Harare, Zimbabwe, 11-13 March 1996.

Matondi, P. (2001) The struggle for access to land and water resources in Zimbabwe: the case of Shamva district. Doctoral thesis, Swedish University of Agricultural Sciences, Uppsala, Sweden.

McGregor, J. (1995) Conservation, control and ecological change: the politics and ecology of colonial conservation in Shurugwi, Zimbabwe. In: Grove, R. and McGregor, J. (eds) Environment and History: Special Issue Zimbabwe 1 (3), 257-279. The White Horse Press, Cambridge, UK.

Mcllwain, R. (1936) Water law in Southern Rhodesia. Rhodesia Agricultural Journal 33, 788-801.

Moore, D.S. (1995) Contesting terrain in Zimbabwe's eastern highlands: the cultural politics of place, identity and resource struggles. Doctoral thesis, Stanford University, Palo Alto, California.

Moyo, S. and Yeros, P. (2005) Resurrecting the peasantry and semi-proletariat: a critique of the new Marxist analyses of land occupations and land reform in Zimbabwe: towards the national democratic revolution. In: Moyo, S. and Yeros, P. (eds) Reclaiming the Land: the Resurgence of Rural Movements in Africa, Asia and Latin America. Zed Books, London and New York, pp. 165-205.

Mtisi, S. and Nicol, A. (2003) Caught in the Act: New Stakeholders, Decentralisation and Water Management Processes in Zimbabwe. Sustainable Livelihoods in Southern Africa Paper Series, Research Paper 20, Sustainable Livelihoods in Southern Africa Research, Brighton, UK.

Nemarundwe, N. (2003) Negotiating resource access: institutional arrangements for woodlands and water use in southern Zimbabwe. Doctoral thesis, Swedish University of Agricultural Sciences, Uppsala, Sweden.

Pearce, G.P.R. and Armstrong, A.S.B. (1990) Small Irrigation Design, Nyanyadzi, Zimbabwe: Summary Report of Studies on Field-Water Use and Water Distribution. Report OD 98, Hydraulics Research, Wallingford, UK.

Pinstrup-Andersen, P. (2000) Introduction. In: Bruns, B.R. and Meinzen-Dick, R. (eds) Negotiating Water Rights. Vistaar, New Delhi, India.

Peters, P. (2004) Inequality and social conflict over land in Africa. Journal of Agrarian Change 4 (3), $269-314$. Phimister, I. (1988) An Economic and Social History of Zimbabwe, 1898-1948. Longman, London and New York. Ranger, T. (1985) Peasant Consciousness and Guerilla War. James Currey, London. 
Rukuni, M. (1993) Irrigation issues in Zimbabwe. Paper presented at the University of Zimbabwe/AGRITEX/ IFPRI Workshop: 'Irrigation Performance in Zimbabwe', Juliasdale, Zimbabwe, 4-6 August 1993.

Rukuni, M. (1994) The evolution of agricultural policy: 1890-1990. In: Rukuni, M. and Eicher, C. (eds) Zimbabwe's Agricultural Revolution. University of Zimbabwe Publications Office, Zimbabwe, pp. 15-39.

Sachikonye, L. (2003) From 'growth with equity' to 'fast-track' reform: Zimbabwe's land question. Review of African Political Economy 96, 227-240.

Sachikonye, L. (2005) The land is the economy: revisiting the land question. African Security Review 14 (3), 3331-3344.

Salman, S. and Mclnerney-Lankford, S. (2004) The Human Right to Water. Legal and Policy Dimensions. World Bank, Washington, DC.

Scoones, I. (1996) Hazards and Opportunities: Farming Livelihoods in Dryland Africa: Lessons from Zimbabwe. Zed Books, London.

Sithole, B. (1999) Use and access to dambos in communal lands in Zimbabwe: institutional considerations. A thesis submitted in partial fulfilment of the requirements for a $\mathrm{PhD}$ at the Centre for Applied Social Sciences, University of Zimbabwe, Harare, Zimbabwe.

SLSA (Sustainable Livelihoods in Southern Africa) Team (2003a) Decentralisations in Practice in Southern Africa. Programme for Land and Agrarian Studies, University of the Western Cape, Cape Town, South Africa.

SLSA Team (2003b) Rights Talk and Rights Practice: Challenges for Southern Africa. Programme for Land and Agrarian Studies. University of the Western Cape, Cape Town, South Africa.

UNDP (United Nations Development Programme) (2003) Human Development Report: Millennium Development Goals: a Compact among Nations to End Poverty. Oxford University Press, New York and Oxford, UK.

UNESCO (United Nations Educational, Scientific and Cultural Organization) (2003) Water for People, Water for Life: the United Nations World Water Development Report. UNESCO and Berghahn, Barcelona, Spain.

Vincent, L.F. and Manzungu, E. (2004) Water rights and water availability in the Lower Odzi watershed of the save catchment. In: Moll, H.A.J., Leeuwis, C., Manzungu, E. and Vincent, J. (eds) Agrarian Institutions between Policies and Local Action: Experiences from Zimbabwe. Weaver Press, Harare, Zimbabwe.

World Bank (1993) Water Resources Management: a World Bank Policy Paper. Washington, DC.

World Bank (2002) Bridging Troubled Waters. Operations Evaluation Department, Washington, DC.

World Bank (2003a) Water Resources Sector Strategy: Strategic Directions for World Bank Engagement. World Bank, Washington, DC.

World Bank (2003b) World Development Report: Sustainable Development in a Dynamic World. World Bank, Washington, DC and Oxford University Press, New York.

WHO (World Health Organization) (2003) Right to Water. Health and Human Rights Series No. 3, World Health Organization, Geneva.

ZCTU (Zimbabwe Congress of Trade Unions) (1996) Beyond ESAP: Framework for a Long-term Development Strategy in Zimbabwe. ZCTU, Harare, Zimbabwe.

Zimbabwe Government (1994) Commission of Enquiry into Appropriate Agricultural Land Tenure Systems (3 Vols). Government of Zimbabwe Printers, Harare, Zimbabwe.

Zimbabwe Government (1998a) Water Act, No. 31/1998. Government of Zimbabwe Printers, Harare, Zimbabwe.

Zimbabwe Government (1998b) Zimbabwe National Water Authority Act, No. 11/1998. Government of Zimbabwe Printers, Harare, Zimbabwe.

Zimbabwe Government (2000a) Statutory Instrument 33. Water (Catchment Councils) Regulations, Harare, Zimbabwe.

Zimbabwe Government (2000b) Statutory Instrument 47 of 2000. Water (Sub-catchment Councils) Regulations, Harare, Zimbabwe.

Zimbabwe Government (2000c) Towards Integrated Water Resources Management. Government of Zimbabwe Printers, Harare, Zimbabwe.

Zimbabwe Government (2003) Report of the Presidential Land Review Committee under the Chairmanship of Dr. Charles Utete (2 Vols). Government of Zimbabwe, Harare, Zimbabwe.

Zimbabwe Human Development Report (2003) Redirecting Our Reponses to HIV and AIDS: Towards Reducing Vulnerability - the Ultimate War for Survival. Produced by the Poverty Reduction Forum, Institute of Development Studies, University of Zimbabwe, Zimbabwe.

Zimbabwe Independent Newspaper (2004) Muckraker Column, 26 November 2004.

Zimbabwe Parliamentary Debates (1998) 25 (26), Tuesday, 3 November 1998. 